\title{
The Influence Of Working Capital And The Effectiveness Of The Use Of The Funds Against The Level Of Liquidity
}

\author{
Dani Iskandar ${ }^{1}$, Muslih $^{2}$, and Cut Lisa Vanisa ${ }^{3}$ \\ \{daniiskandar@umsu.ac.id ${ }^{1}$ \} \\ ${ }^{1,2,3}$ University Of Sumatera Utara, Jalan Kapten Mukhtar Basri No. 3 Medan, Indonesia
}

\begin{abstract}
The provision of working capital that exists in companies used to finance their operations and pay the debts owned including short-term debt. The effectiveness of the use of the funds will also help companies gain an advantage that will increase the addition of cash owned so that the liquid current assets can be provided and the dperoleh company. Therefore the provision of working capital and the effectiveness of the use of funds will greatly help the company improve likuditas. The purpose of this research is to know the influence of capital; the work and effectiveness of the use of the funds against the level of liquidity in the PT. (Persero) Plantation Nusantara IV Field. Methods of data analysis used was multiple linear regression using SPSS version 22. With data capture of skunder PT. (Persero) Plantation Nusantara IV Field. The research results are the working capital have significant influence towards the level of liquidity in the PT. Nusantara IV Plantation Field. Test results showed that the hypothesis partially $t$ calculate $>t$ table $8.646>3.182$. Therefore $t$ count is 0 , so the rejection area Ho (Ha accepted). Use of funds have significant influence towards the amount of liquidity on the PT Nusantara IV Field Plantations, with a level of significance of each is of 0.008 and results processing of data obtained is amounting to 5.040. Test results showed that the hypothesis partially $t$ calculate $5.040>\mathrm{t}$ table $>3.182$. Therefore $\mathrm{t}$ count is in denial, so Ho Ho (Ha accepted). From Anova test in may F count of 16.510 significantly 0.000 whereas $\mathrm{F}$ table of known is of 6.66. Based on those results can be known that F F > count table so that the hypothesis proposed is acceptable there are influences of working capital and the use of funds against the level of liquidity in PT Nusantara IV Field Plantations.
\end{abstract}

Keywords: working capital, the use of funds and liquidity

\section{Introduction}

Every business entity engaged in the fields of industry, services, and trade certainly realize the importance of working capital for the company. With the availability of sufficient working capital will allow the company running the day-to-day operational activities properly. Without the company's working capital would be the difficulty in financing its operational activities in addition to pay short-term debt-debt that will be maturing. In the management of working capital must be through good planning, so that in the future not found excess or shortage of working capital that can hinder the efficiency and effectiveness of the company. By performing the analysis of the sources and uses of working capital management, then will know the position or change in working capital, where this can be useful when at a later date the management will take a wisdom related to the company's financial circumstances.

In the life of a company, the problems always arise especially regarding working capital needs. The answer that was provided to the question regarding the working capital was that the company working capital shortage, so the company is kind of hard doing activities in order 
to gain profit for the sake of guaranteeing growth and continuation of the life of the company. The answer is still apocryphal, whether the company is indeed a shortage of working capital or less effective in the use of working capital. The company should be able to construct a steady over the planning of working capital, working capital instead managed the analysis needs to be done. So companies can make a discretion over working capital.

Working capital is a fundamental requirement that are necessary for the life of the company to finance its operations. A number of funds that have been expended to fund the operation, expected to be able to go back again into a relatively short period of time through the company's business results in money coming into the company are sourced from the sale of business results the company will be issued back in order to finance the company's operations. Thus the Fund will continue to spin each period features. Working capital management is closely associated with the principles of the budget. To be achieved a good management of the funds used, companies need to pay attention to the application of the principles of the expenditure, that is balanced with the need for working capital in the company.

One measure of the success of financial managers in the exercise of his duties is the success of pengeloaan working capital because capital management work closely related to daily business activities and the survival of the company. The funds needed by the company for the activities of daily membelanjai are referred to as working capital, working capital is an investment company in the form of cash, accounts receivable, inventory and other current assets in the form of lannya, hence working capital very important in the company because without working capital the company can not meet the needs of the Fund in carrying out its activities. Working capital turnover period i.e. when cash embedded in elements of working capital to be cash back. Working capital turnover period showed the efficiency of use of working capital. The faster rotation of the working capital shows the more efficient use of working capital and investments in working capital is getting smaller therefore finance manager sued for mengefisiensikan working capital turnover so that will help an increase in the use of funds will eventually have an impact on obtaining maximum profits.

Working capital in addition to internal company is also useful for parties outside the company, such as shareholders, creditors, Governments, and other parties who would like to mengetauhi the State of the company. by studying the analysis of working capital, then shareholders will be able to assess the performance of the company through working capital they instill this long if the company already generates the appropriate profit level, which is reflected in the price menanjaknya the company's shares on the stock market. The borrower is obliged to know the degree of liquidity of the company, which is associated with the belief of the borrower to provide assistance to credit to the company, creditors can also tell if a credit will be given it enough got a guarantee from the company, which is visible on the company's ability to generate profits in the future.

PT. Plantation Nusantara IV, is a company perkebunanan that urgently need working capital to finance daily operations, working capital is therefore urgently needed by the company.

\section{Theoretical Foundation}

\subsection{The notion and function of working capital}

Working capital is the heart of the company's activity. For companies that are unable to foresee the needs for working capital, will experience obstacles in the operating activities of the company. Therefore the amount of working capital needed by enterprises must be planned 
properly. A number of funds that have been expended to fund the operation, expected to be able to go back again into a relatively short period of time via the results of sales of products of the company. the money coming into the company are sourced from the sales results of the company's production will be issued back in order to finance the company's operations. Thus the Fund will continue to spin each period features.

For more details about the importance of working capital within the company the following has been said then the opinions of experts such as:

According to Munawir (2011:19) "Capital is right or part owned by the owner of the company that in the post capital (share capital), surplus and earnings on hold". According to Martin (2015:3) "traditionally, working capital (working capital) is defined as the company's investment in current assets (current assets)". Djarwanto (2011:91) "working capital is the excess of current assets against short-term debt. The excess is called net working capital (net working Capital) is the amount of current assets that originates from long-term debt and private equity ".

According to Ridwan Sundjaja \& Inge Barlian (2013:185) "working capital is the cash/bank letter, - securities that are easily spent (eg checking, check deposits), trade accounts receivable and inventory cycle all its level not exceeding 1 year or period of operation a normal company. "

According to Bambang (2011:49) "the concept of working capital in the companies divided 3 namely:

1. A quantitative concept, the concept is based on the quantity of funds that are embedded in the elements of the current assets where these assets is assets which once spun back in the form of funds or assets which are embedded in it will be able to free again in a short time.

2. The concept of qualitative, qualitative concepts when working capital was only associated with the large amount of current assets, then on a quantitative understanding of this concept of working capital is also associated with a large amount of debt or debt that must be smooth promptly paid.

3. They provide Concepts, the concept is based on the functions of the Fund in generating revenue. Any funds used in an income-producing period.

The factors that Determine the magnitude of working capital, working capital which is pretty is very important for the company, because with enough working capital, the company will be able to carry out activities of daily operasioanalnya in an efficient and effective it is means the working capital is not too little and not too overwhelming.

According to Munawir (2015:91) there are 5 factors that determine the magnitude of the needs for working capital, namely:

1. The nature or type of the company

2. The time needed to produce an item and the price of the item

3. The terms of the purchase of materials or merchandise

4. Terms sales

5. Inventory turnover rate

\subsection{Understanding and elements of Debt Smoothly}

Debt is all the financial obligations of the company to another that hasn't been fulfilled puhak. The obligation is the claim of an individual or a group against the wealth of the company, in this case there are assets of the company. In General, all the obligations or debt that is paid in money, but also the debt can be paid with goods or services. There are two types of debt that is smooth and debt long-term debt. 
According to Munawir (2015:18) defenisi smooth debt is as follows: "debt short-term debt or smoothly is the financial obligations of the company, the pelunasannya or the payout will be done in the short term (one year from the date of the balance sheet), by using current assets owned by the company ".

\subsection{Types and elements of working capital}

The availability of working capital that can be used immediately in operation dependent on the type and nature of current assets owned by such as: cash, securities, accounts receivable and inventory. But the amount should be enough working capital in the sense must be able to finance the expenditure-expenditure or the operation of the company's everyday, because with enough working capital would be profitable for the company in addition to allow the company to operate economically or efficiently and companies are not experiencing financial difficulties, but it will also give you an advantage.

Working capital available in the company is made up of various types, according to Bambang (2011:55) are:

a. Permanent working capital i.e. working capital that must remain at the company to be able to execute its functions to smooth business.

b. Working capital variables i.e. working capital whose number varies according to the changing circumstances.

\subsection{Analysis of the sources and uses of working capital}

At the end of the company's accounting, usually priode will publish the financial statements. Published financial report include the balance sheet, income statement, and report profits on hold. But there are times when companies publish financial statements, other reports, such as the source and use of funds. The report takes as a tool of financial analysis is very important for the Finance Manager, the lender or the bank in assessing the credit worthiness will be given to the company. with the analysis of the source and use of funds, will note how companies manage and use the funds.

Report the source and use of funds, there are two opinions about the notion of funds. The first sense is defined as working capital as expressed by Erwan (2010:2) "funds are more often defined as working capital, and in this report the funds will report about the activity of working capital".In other words the report sources and uses of working capital describes a summary of seumber and the use of working capital and change in working capital elements during priode is concerned. The second sense according to Erwan (2010:3) "refers to a Fund with cash. Or in other words the source and use of funds a summary of the source and describe the use of cash during the priode is concerned, or often called as well as the cash flow statement".

\subsection{The Working Capital Ratio}

In short, financial ratios describe a relationship between a certain amount by the number of the other, which is useful for giving an overview about the overview of the circumstances or the financial position of a company. According to Harahap (2013:297) financial ratios is "Numbers obtained from the results of a comparison of a post financial reports with the other post that has the relevant and significant relationship/meaning".According to Bambang (2015:329) there are two (2) basic commonly used in analyzing financial ratios as follows:

1. Compare company financial ratios-ratio at the time now (the present ratio) with ratiofinancial ratio of time ago (historical ratio). 
2. Comparing financial ratios-ratio of a standard ratio of firms with similar companies.

Every company is aware of the importance of analysis of financial ratios-ratio, as with the analysis of the financial statements, it would be useful to know to what extent the company performance levels that have been reached in the priode. in this case the management can find out whether the financial performance of companies undergoing development or not, in terms of liquidity, solvency, profitability, or activity so that companies can find out weaknesses, so that in the preparation of plans for the next year, the kelemhan-weaknesses can be corrected. The working capital ratio related to the liquidity of the company i.e. the ability of a company to pay financial obligations at the time charged. The company said that if the company is a liquit has the power of paying out are so great that the company is able to meet all financial obligations that are immediately filled. Conversely if the company does not have the power of financial liabilities payment immediately then the company is said to be inlikuit. The working capital ratio stress analysis and menginterprestasikan of short term financial position of the company, in addition to seeing the level of efficiency of the working capital that was used by the company.

According to Munawir (2011:72-80) financial ratios is divided into five (5) types, namely:

1. Current ratio

2. Acid test ratio

3. receivable trun over)

4. inventory turn over)

5. working capital turn over)

\subsection{Control Of Working Capital}

To answer all of those questions, then the control of working capital is to increase and maintain the liquidity of the company. One of the conditions for maintaining the liquidity of the company is to use the principle shopping pairing. The principle of the paired spending intended that a period of availability of funds for the company, should not be shorter than a period of usage of these funds in the company, in other words the need for short-term capital can be financed with short term loans, but it should be financed with its own capital.

Thus to maintain the liquidity of the company that first applied is a period of usage of funds in the company or how long those funds in the company. based on that, we can specify how long it should be on borrowed funds and provided for the company. for company financial institutions such as banks and insurance companies, applies the principle of reverse. Current ratioyang high from the point of view of the lender is considered quite good, but from the point of view of shareholders are considered less profitable, because current assets not in use with effective power. Reverse current ratio that is low in relatively more risky, but it indicates that management has been operating current assets effectively.

According to Areyouredsquirrel (2015:2) Current ratio may be enhanced by road:

1. With debts of certain seamless, laboured to add to current assets

2. With certain current assets and tried to reduce the amount of debt smoothly

3. By reducing the amount of debt smoothly together with reduced current assets

\subsection{Understanding Liquidity}

Liquidity ratio describes the ability of the company to settle short-term liabilities. (Harahap, 2013:301).The liquidity ratio is a ratio that measures the company's ability to meet short-term obligations with current assets available. Liquidity ratio analysis is used to find out the kemamuan company to meet short-term obligations due. (Sundjaja and Barlian, 
2011:108)Liquidity problems are related to the issue of the ability of a company to fulfil the obligations of finansiilnya must be met immediately. The amount of payment tools (Tools liquid) owned by a company at a particular time is the power of pay from the company concerned. A company that has the power to pay so great that is able to meet all obligations of the finansilnya soon to be fulfilled, it is said that the company is liquid and vice versa does not have the ability to pay is illikuid. Not only banks and short-term Creditors are interested in figures against the working capital ratio, i.e. the ratio that is used to analyze and menginterprestasikan short term financial position, but is also very helpful for management to check the efficiency of the working capital that are used within the company, it is also important for the long-term creditors and shareholders who eventually or at least like to know the prospects of dividend and interest payments in the future.

\subsection{The Influence Of Working Capital With Liquidity}

Accounts receivable reflects the number of bills over other companies over money, goods, services and other non cash assets. Accounts receivable is recognized only when the recognition criteria have been met. Theoretically receivable arising from the sales of goods or services in credit should be reported in the balance sheet of a net worth actually realized or expected values are acceptable. This means that accounts receivable should be recorded from pieces of the sales price that is diantisipasikan. The goal is to report accounts receivable with the rights to the number of customers who really expected to be able to accept payment by cash or credit.For many of the company's revenue from the sale of the credits is the largest element of the effect on net income. If a company bought in credit, receivables arising shall be calculated which is probably the most important elements of the current assets. Accounts receivable current assets component of most large numbers so that the degree of liquidity of a company. According to Bambang Arwana (2004, p. 18) States that "the liquidity of the company is the ability to finance the financial obligations associated with in organizing production, while sales growth has a direct relationship against investment against current assets that are the source of funds that can be used to meet the needs of companies, among others, to organize production and financing against debt-debt that will soon be due. According to Weston (2004, p. 413) "sales growth has a relationship very closely and directly with the investment in the form of current assets grew, the company must raise sales accounts receivable, supplies and money kasnya any need also raised.

\section{Research Methods}

The type of research used in this research is the use of Associative research. This type of research is intended to test the influence of independent variable i.e. working capital and the use of funds against liquidity according to the STATE-OWNED ENTERPRISES. Next will be described how each independent variable explain the dependent variable.In this case studies get the data sourced from PT (Persero) Perkebunanan Nusantara IV Field data in the form of financial statements, for example the amount of working capital, the amount of debt owned by the company smoothly and report data balance sheets. Types of data used in this study is documentary data i.e. data about the brief history of the company, its organizational structure and Division of tasks and functions and benefits of the financial statements. To collect data in accordance with necessity, the author uses the method of data collection in a way that is: the study of documentation, i.e. studying the documents related to the problem or research data such as company financial reports and others. 
Data analysis techniques used in this research is to use the linear regression assuming a processed with SPSS 18 . The analysis step is carried out by the following stages: a descriptive statistical tests, Classic Assumption Test, Multicollinearity, normality,Autocorrelation,Heteroskedastisitas Test, Multiple Linear Regression, Hypothesis Testing.

\section{Results And Discussion}

Based on the results of the processing of data obtained in the test results obtained by multikolinieritas can be seen in the following table:

Table 1. Coefficients

\begin{tabular}{|c|c|c|c|c|c|c|c|c|}
\hline \multicolumn{9}{|c|}{ Coefficientsa } \\
\hline \multirow[t]{2}{*}{ Model } & \multicolumn{2}{|c|}{$\begin{array}{l}\text { Unstandardized } \\
\text { Coefficients }\end{array}$} & \multirow{2}{*}{$\begin{array}{l}\text { Standardized } \\
\text { Coefficients }\end{array}$} & \multirow[t]{2}{*}{$\mathrm{t}$} & \multirow[t]{2}{*}{ Sig. } & \multicolumn{3}{|c|}{ Correlations Statistics } \\
\hline & B & $\begin{array}{c}\text { Std. } \\
\text { Error }\end{array}$ & & & & $\begin{array}{l}\text { Zero- } \\
\text { order }\end{array}$ & Tolerance & VIF \\
\hline (Constant) & 39.881 & 6.458 & & 6.176 & 0 & & & \\
\hline $\mathrm{X} 1$ & 0.266 & 0.094 & 0.268 & 2.832 & 0.006 & 0.319 & 0.502 & 1.265 \\
\hline $\mathrm{X} 2$ & -0.278 & 0.081 & -0.335 & - & 0.001 & $-\overline{0}-232$ & 0.559 & 1.321 \\
\hline
\end{tabular}

Depen

Berdasarkan hasil data diketahui bahwa nilai variance Inflation Factor (VIF) untuk variabel modal kerja $\left(\mathrm{X}_{1}\right)$ adalah sebesar 1,265, variabel penggunaan dana $\left(\mathrm{X}_{2}\right)$ sebesar 1,321, dari masing-masing variabel independen tidak memiliki nilai yang lebih dari nilai 10 . Nilai tolerance pada untuk variabel modal kerja $\left(\mathrm{X}_{1}\right)$ adalah sebesar 0,502 , variabel penggunaan dana $\left(\mathrm{X}_{3}\right)$ adalah sebesar 0,559. Nilai tolerance lebih besar dari 0,1 sehingga dapat disimpulkan bahwa tidak terjadi gejala multikolinieritas antara variabel independen yang diindikasikasikan dari nilai tolerance setiap variabel independen lebih besar dari 0,1 san nilai VIF lebih kecil dari 10. Maka dapat disimpulkan bahwa analisis lebih lanjut dapat menggunakan model regresi berganda.

Koefisien determinan $\mathrm{R}$ Squere $\left(\mathrm{R}^{2}=\right.$ koefisien Determinasi) menunjukkan sebesar variabel independen menjelaskan variabel dependennya. Nilai $\mathrm{R}$ Squere $\left(\mathrm{R}^{2}\right)$ berada diantara 0 dan 1. Nilai $\mathrm{R}^{2}$ nilai semakin mendekati satu, maka variabel-variabel independen dapat memberikan semua informasi yang dibutuhkan untuk memprediksi variasi variabel dependen. 
Tabel 2. Coefficientsa

\begin{tabular}{|c|c|c|c|c|c|c|c|c|}
\hline \multirow[t]{2}{*}{ Model } & \multicolumn{2}{|c|}{$\begin{array}{l}\text { Unstandardized } \\
\text { Coefficients }\end{array}$} & \multirow{2}{*}{$\begin{array}{l}\text { Standardized } \\
\text { Coefficients } \\
\text { Beta }\end{array}$} & \multirow[t]{2}{*}{$\mathrm{t}$} & \multirow[t]{2}{*}{ Sig. } & \multicolumn{3}{|c|}{ Correlations Statistik } \\
\hline & $\mathrm{B}$ & Std. Error & & & & Zero-order & $\begin{array}{l}\text { Toleranc } \\
\mathrm{e}\end{array}$ & VIF \\
\hline 1 (Constant) & 39.881 & 6.458 & & 6.176 & 0 & & & \\
\hline $\mathrm{X} 1$ & 0.266 & 0.094 & 0.268 & 2.832 & 0.006 & 0.319 & 0.502 & 1.265 \\
\hline $\mathrm{X} 2$ & 0.278 & 0.081 & -0.335 & $3.438^{-}$ & 0.001 & -0.232 & 0.559 & 1.321 \\
\hline
\end{tabular}

Dependent Variable: Y

Based on the results of the data it is known that the value of the variance Inflation Factor (VIF) for working capital variable (X 1) is of 1.265, variable use of funds (X 2) of 1.321, of each independent variable does not have a value that is more than the value of the 10 . The value of tolerance on to variable working capital (X 1) is of 0.502 , variable use of funds (X 3 ) is of 0.559 . Tolerance value greater than 0.1 so that it can be concluded that the symptoms do not occur multikolinieritas between the diindikasikasikan independent variable from the value of each variable independent tolerance greater than 0.1 san VIF values smaller than 10 . It can be concluded that further analysis can use the multiple regression model.

Determinant of the coefficients $\mathrm{R}$ Squere ( $\mathrm{R} 2=$ the coefficient of Determination) indicates the independent variable explain the variable of dependennya. The value of $\mathrm{R}$ Squere (R2) between 0 and 1 . The value of R2 value of getting closer to one, then the independent variables can provide all the information needed to predict the variation in the dependent variable.

Multiple linear regression influence results shown in the table as follows:

$$
\begin{aligned}
& \mathrm{Y}=\mathrm{b}+\mathrm{bX} \mathrm{X}_{1}+\mathrm{bX} \mathrm{X}_{2}+\mathrm{e} \\
& \mathrm{Y}=39.881+0.266+0.278+0.055+4
\end{aligned}
$$

Description:

$\mathrm{Y}=$ Cash earnings

$\mathrm{X}_{1}=$ Working Capital

$\mathrm{X}_{2}=$ Use Of Funds

'E = The Level Of A Bully Errors

Description :

1). The constants of the positive relationship with the direction 39.881 showed that when the independent variable is considered constant then the liquidity (LK) experienced an increase of Rp. or 39.88139 .881 .

2). $\beta 1$ of 0.266 with the direction of the positive relationship indicates that any increase in the use of funds it will be diiringin with an increased amount of liquidity rate of 0.266 or amounting to $\mathrm{Rp} 266$, assuming the other independent variables are considered constant.

3). $\beta 3$ of 0.055 with the direction of the positive relationship indicates that any increased liquidity it will be followed by a capital increase in cash of employment earnings 5.5 or $0.055 \%$ assuming other independent variable is considered constant.

Tabel 3. Coefficients ${ }^{\mathrm{a}}$ 


\begin{tabular}{|c|c|c|c|c|c|}
\hline \multirow[t]{2}{*}{ Model } & $\begin{array}{l}\text { Unstandardized } \\
\text { Coefficients }\end{array}$ & $\begin{array}{l}\text { Standardized } \\
\text { Coefficients }\end{array}$ & \multirow[t]{2}{*}{$\mathrm{t}$} & \multirow[t]{2}{*}{$\mathrm{t}$} & \multirow[t]{2}{*}{ Sig. } \\
\hline & B $\quad$ Std. Error & Beta & & & \\
\hline (Constant) & 25.855 & 14.455 & & $8-.648$ & .000 \\
\hline MK & .841 & .541 & .227 & 5.040 & .008 \\
\hline $\mathrm{PD}$ & .140 & .038 & .811 & 4.707 & .006 \\
\hline
\end{tabular}

Statistical tests $t$ basically shows how far the influence of one independent variable individually in the dependent variable explained variation (Ghozali, 2005). From the results of the partial regression analysis based on the table above, it can be summed up as follows:

1. Independent variable i.e. working capital have significant influence towards cash earnings, with the level of significance of each is 0000 this is because the value of their significance is greater than the significance level used that is $5 \%$. $(\mathrm{dk}=5-2=3$ yaitu3,182). and the results of processing the data obtained is amounting to 8.646. Based on the results of data on top of research results obtained regarding the use of working capital had a significant influence on liquidity terhadaptingkat PT. Perkebunanan Nusantara IV Field. Test results showed that the hypothesis partially $t$ calculate $>t$ table $8.646>3.182$. Therefore $t$ count is 0 , so the rejection area Ho (Ha accepted). So in conclusion there was significant influence between the working capital towards level likuidtas PT. Perkebunanan Nusantara IV Field

2. Use of funds have significant influence towards the amount of liquidity on the PT Nusantara IV Field Plantations, with a level of significance of each is 0.008 since their significance value smaller than the level of significance of $5 \%$ that is used. ( $\mathrm{dk}=5-2=3$ i.e. 3.182) and the results of processing the data obtained is amounting to 5.040. Based on the results of data on top of research results obtained regarding the use of the funds has a negative and significant effect against the likuiditasPada level of PT Nusantara IV Field Plantations. Test results showed that the hypothesis partially t calculate $5.040>\mathrm{t}$ table $>3.182$. Therefore $t$ count is in denial, so Ho Ho (Ha accepted). So in conclusion there was significant influence between the use of the Fund has a positive and significant influence towards the level of liquidity in the PT. Nusantara IV Plantation Field.

\section{Conclusions}

Based on the results of the data processing on this chapter will reveal the conclusions of researchers data sources and note that the use of funds in pt. (Persero) Plantation Nusantara IV Field is still less well because the lack of balance between the acceptance with spending so that likuditas factor obtained is still insufficient and assessed less well.

1. There is the influence of use of working capital against the level of liquidity in PT. Perkebunanan Nusantara IV Field

2. There is the influence the effectiveness of the use of the funds against the level of liquidity in pt. Perkebunanan Nusantara IV Field

3. There is the influence of use of working capital and the effectiveness of the use of the funds against the level of liquidity in PT. Perkebunanan Nusantara IV Field

\section{Suggestions}

As for a few suggestions that may be input means for the company, among other things: 
1. It is recommended that the management company to use or benefit from the asset to its full potential, for example, leverage existing assets that are less well functioning so that the activity of the company is running better then it is thereby expected profit gain the company will increase.

2. The source of the cash infusion that is owned by the company needs to be improved, so that the rotation of the source and use of the cash the company will continue to increase.

3. Should be in the management of cash, companies are focusing more on allocation from the Treasury, so that the elements of the current assets is intended to maintain the liquidity of the company can be tailored to suit previous planning or in other words abuse does not occur from the cash in the future.

4. It is recommended that the company correct the decline experienced so there is an increase in either the acceptance of cash or resources.

\section{Reference}

[1] Bambang Riyanto (2015), The basics of Corporate Spending, the sixteenth edition of the Three Prints Publisher Gadjah MadaDjarwanto PS (2011), Fine points of analysis of financial statements, Fifth Edition, first printing of Yogyakarta Publisher BPFE

[2] Erwan R Wibowo (2010) Principles of accounting, Jakarta, the sixteenth edition of the first volume, Eason

[3] Hadibroto, S (2011) The Accounting Problems, The Publisher's Jakarta Indonesia University Faculty Of Economics

[4] Harahap Sofyan, (2015). Principles of marketing, a successful Management in the developing Countries. Jakarta, The Fourth Mold, Publisher: Erlangga

[5] Ikatan Akuntansi Indonesia (2015). Financial Accounting Standards. Salemba Jakarta: Four.

[6] JD. Wilson (2013), Task Management, Accounting Controllership Translation Agus Maulana Jakarta; The Third Edition Of The Publisher Erlangga.

[7] Munawir S (2011), Financial Statements Analysis, Fourth Edition, The Fifth Mould, Yogyakarta; Liberty

[8] Niswonger C. Rollin (2012) Principles of accounting, translation of Hygenus Ruswirarto and Herman Wibowo. Vol I Issue 16 in Jakarta.

[9] Simangungsong A. O (2013) The basics of financial accounting, Jakarta, third edition, Publisher Universitas Indonesia.

[10] Sugiono (2016) Business Research Methods, The First Publisher Prints Alfabeta Bandung

[11] Smith Skousen (2011), Intermediate Accounting, Publisher Of Alphonsus Sirait, Bandung, First Printing; Publisher Erlangga 
